\title{
Intensive reading skills with cooperative integrated reading composition (CIRC) and group investigation (GI)
}

\author{
Ika Panggih Wahyuningtyas ${ }^{1}$, Ermanto ${ }^{2}$, Abdurahman $^{3}$ \\ ${ }^{123}$ Universitas Negeri Padang, Padang - Indonesia, (ikapanggihwahyuningtyas@gmail.com)
}

\begin{abstract}
This research aims to know the difference in the results of learning to read with intensive using the model of the CIRC and learning motivation of GI in grade VII MTs Country Muara Bulian. This type of research was quasi experiment (experiment of the artificial) and design used in this study is a $2 \times 2$ factorial. This research population is students of Class VII MTs Country Muara Bulian. First, The average reading skills of students who are taught in an intensive learning CIRC. was 81.00, while students taught with model GI was 79.40. Both, the average the learning model CIRC. is 83.25, students learning motivation high taught with model GI was 84.40 . Third, the average reading skills of students ' learning motivation low intensive taught by learning model CIRC. was 78.75 and taught with model GI is 74.40 .
\end{abstract}

Keywords: the difference, read-intensive, CIRC, GI, learning motivation

\section{Introduction}

Read basically to search for information, including the content, and understand the meaning. Understand the meaning of closely association with the purpose of reading, one that understand the meaning, content and information is reading intensive. Intensive Reading is read carefully, carefully, carefully, and slowly with the aim to understand the whole.

Based on observation and interview on the study has been done, there are some problems that appear in learning to read intensive . (1) Student cannot understand texts that consist of several paragraphs properly so that the Department cannot questions that relate to the readings are read intensive reading in particular. It can be observed when reading materials given to students, students experience the confusion in the questions. (2) the ability of the students in understanding the very low readings. evidenced by the results of student tests that can not answer teacher questions 3) students love reading, especially intensive reading.

Motivation according to Mc Donald's (1979:52) is a discussion of energy within a person which is characterized by the onset of feelings and reactions to achieve a goal. Motivation starts from any change of energy in private. Motivation to learn can arrange because of various things, can be a boost from within the individual self and encouragement from outside the individual self.

Based on the issue that has been addressed, researchers intend to research that aims to find out the influence of the use of the donation or learning model CIRC. and GI in intensive reading learning in 
grade VII VII MTs Country Muara Bulian. According to James 1. Collins Dkk (2016:1) we took out the hypothesis that the integration of reading and writing through writing-assisted instruction will produce greater gains in reading comprehension than a regular class instruction that does not integrate reading and writing. So Pembelaran CIRC. is kalaborasi between reading and writing.

In addition, researchers also intend to research to see the difference in the results of intensive learning to read by using the learning model CIRC. and GI in grade VII MTs Country Muara Bulian. Therefore, the study entitled "the distinction ability of Intensive Reading by using the Learning Model Cooperative Integrated Reading and Composition (CIRC.) and Group Investigation (GI) Reviewed the learning Motivation of Students of Class VII MTs Country Estuary Bulian, "it is important to implement.

\section{Methods}

Type of this research is quantitative research. Quantitative research is research that seeks to acquire the correct knowledge based on concepts, variables, reliability, and operational. Sugiyono (2010: 14) explains that quantitative research methods can be defined as a method of research based on the philosophy of positivism, used for researching on population or a particular sample, techniques sampling done purposive sampling, data collection using the research instrument, the quantitative nature of the data analysis/statistics with the aim to test the hypothesis that have been applied. This research uses the test as of the instrument and the question form to measure the learning motivation of students, then conducted data analysis techniques using the test of its homogeneity and normality test. Quantitative research is done by determining the population, then the specified sampelnya of the population so that research can be done. The design used in this study is a $2 \times 2$ factorial design Students are grouped into two classes, namely class experiment I and experiment II. Experimental class I is the class of the selected writers to apply model CIRC., whereas class II experiment to apply the model of the GI. Next look at the keterukuran level of the motivation of students in melajar using model CIRC. and GI.

This is the entire research Population grade VII Muara Bulian State MTs. listed on the school year 2017/2018 . The students scattered into five classes with a total of 152 people. Arikunto (2006:130) explained that the overall population is a subject of research. Sampling done by the technique of purposive sampling. Sugiyono (2010:124) States that purposive sampling is a technique of determining the sample with a particular consideration. This research is needed on two sample classes, i.e. classes of experiment I and class II experiment.

Research instrument was drawn up on the basis of existing theory and adapted to the indicators that support this research. The steps in preparing the test instrument are as follows. First, the creation of a grid based on the indicators test. Second, Make now the motivation to learn, the third, the preparation of indicators based on objective test question. Fourth, doing rational analysis to look at the suitability of the matter objectively measured aspects with.

The process of drafting an objective test instruments sheet is done with the following steps. First, the creation of a grid of indicators that have been derived from the theory used. Second, the arrangement of the details of the question in accordance with the indicators of objective tests. Third, rational analysis to look at the suitability of the grain problem with indicators as well as the appropriateness of drafting a matter in terms of the aspects measured. Fourth, consult with the supervisor to retain the validity of grain in accordance with construction. Objective test developed by referring to the concept of intensive reading with the lattice test objective.

Analysis data aims to test the hypothesis put forward in the study. From data obtained then do Analysis the data by performing a test of hypotheses about the average grade of the sample of the study. Data that has been collected is analyzed through the following stages. 
Analysis data is done as follows. First, check out the answer sheet are filled by students. Second, give the score against results of intensive reading students based on aspects of the researched. Third, change the value of the score being based on (a reference Benchmark Assessments). To change the value of the score being used the formula percentages. This percentage formula aims to determine the level of mastery of students ability in intensive reading. According to Abdurahman and Ratna (2003:264) to calculate the value of the obtained formulas based on a percentage of students do. Fourth, determine the average value of intensive reading skills count at grade Muara Bulian State MTs VII by using the following formula (Abdurahman and Ellya Ratna 2003:270). Fifth, interpreting the results of learning to read -intensive in students based on average to calculate and KKM. Sixth, the results of the calculation with the formula that transformed into a scale being used. For it is necessary a minimum benchmark of mastery as a benchmark the success of students. In this case use a scale of 10. Furthermore, the data analysis the results of this research uses statistical methods to see intensive grade reading skills Muara Bulian State MTs VII . The data were analyzed using two difference test average. To determine the formula of difference of two trials the average worn done its homogeneity and normality test data obtained.

Seventh, create a bar chart about the results of student learning in intensive reading. Eighth, analyzing data results of research using statistical methods to see intensive reading skills in grade VII MTs Country Muara Bulian. The data were analyzed using two difference test average. To determine the formula of difference of two trials the average worn done test normality and homogeneous data retrieved. First, Test For Normality. Second, Its Homogeneity Test, Third. The test of hypothesis Testing hypothesis 1 hypothesis, hypothesis 2 and 3 using the formulat -test and the fourth hypothesis testing using analysis of variance (anava) test f. According to Riduwan (2012:222), two lines of anava is used to test the hypothesis comparisons more than two samples and every sample is composed of two or more types together. In this case there are three hypotheses that can be tested, namely existence of interaction, the interaction does not occur, and there is no interaction towards something that is compared.

\section{Discussion}

In this discussion, outlined four principal studies associated with reference to relevant theory. First, the difference in the model and the CIRC. model GI against intensive reading skills. Secondly, the intensive reading skills of students with high motivation of learning taught by the model and the CIRC. model GI. Third, the intensive reading skills of students with low learning motivation are taught with the model CIRC. and model GI. Fourth, the interaction between the model and the CIRC. model GI with the motivation of learning in intensive reading skills affect.

Before the intensive reading skills test is performed, the level of skill between the experimental class I and class II experiment in reading is believed to already be different. The assumption that this was prudent due to the difference of treatment applied to the sample in the second grade learning reading intensive. During the process of learning was grade experiment I and II experiment class feel the atmosphere of different learning in intensive reading. This is because the class experiment I used the model of the CIRC. Going but in the experimental class II using model GI.

The difference in ability in both classes is addressed by the average score of different intensive reading skills. verage read intensive experimental class I is not much different than the experimental class II. The average skill of class I in the intensive reading experiment was 81.00 up CIRC. KKM is set and is a qualifying good (B). This is due to the influence of the treatment set forth in the experimental classes I use model Circ. is, however, not much different from the experimental class II that uses model GI. The average GI students experiment class skills II intensive reading in the IE upper GI was $79.40 \mathrm{KKM}$, however the average value obtained by the experimental class I is higher than the 
average of the values obtained by the experimental class II. The following will be described in more detail description of intensive reading skills students class experiments I and ekaperimen II class.

The results of hypothesis testing the first research shows that in General there is no difference between the intensive reading learning results of students taught with the learning model CIRC. with students being taught learning model with GI in grade VII MTsN Muara Bulian. The average reading skills of students who are taught in an intensive learning CIRC. was 81.00, while students taught with model GI was 79.40. As with the role of the teacher in the learning activities in the textbook, the role of the student is not declared explicitly as well. The explicit statement of the role of students in general are written on the instructions of the teacher. Because it tends to be expressed implicitly, teachers need to perform inference of the role of students in most learning activities. In order for students to become acquainted, in terfasilitasi care, and internalize characters, students should be given an active role in learning.

The second hypothesis test results show that the There is no difference between the intensive reading learning outcomes of students who have a high learning motivation are taught with a model of learning that students with CIRC. have the motivation of high learning taught by learning model GI. The average reading skills of students ' learning motivation high intensive taught by learning model CIRC. was 83.25 high learning motivation while students taught with model GI was 84.40.

The third hypothesis testing Results indicate that there is no difference between the intensive reading learning outcomes students with low learning motivation are taught with a model of learning that students with CIRC. have low learning motivation taught learning model with GI. The average reading skills of students ' learning motivation low intensive taught by learning model is whereas 78.75 CIRC. students learning motivation are low GI model being taught was 74.40.

An interaction occurs when one of the factors that effect depends on other factors in the something (Irianto, 2004:225). This means each factor between CIRC. and GI with the motivation of studying interdependent of each other in influencing skills reading intensive. The process of interaction between the variables can be explained as follows.

Learning motivation can determine success in intensive reading skills. Many other factors as supporting such a motivation, interest, intelligence, talent and so on. In addition, the readiness factors of teachers in using the model of learning in the GI and CIRC. read intensive will also be influential in the outcome of the intensive students learn to read. There is no interaction between the model and the model CIRC. GI with the motivation of learning can also be seen from the results of the average intensive reading skills test. As seen in the following graph of the interaction.

Based On Image 01 these can be known that point A is a group grade experiment I have learning motivation high with the average value 83.25 , point to $\mathrm{D}$ is a group of students class experiments II which has learning motivation high with the average value 84,40 , point $C$ is a group grade experiment I have learning motivation low with the average values obtained 78.75 , and point B is a group of students class experiments II which has learning motivation low with the average value obtained 7440 . With No presence of pieces of the line indicated by the graph, it can be inferred that there is an interaction between the model of learning with the learning motivation of students reading skills against intensive class VII MTsN Muara Bulian. 


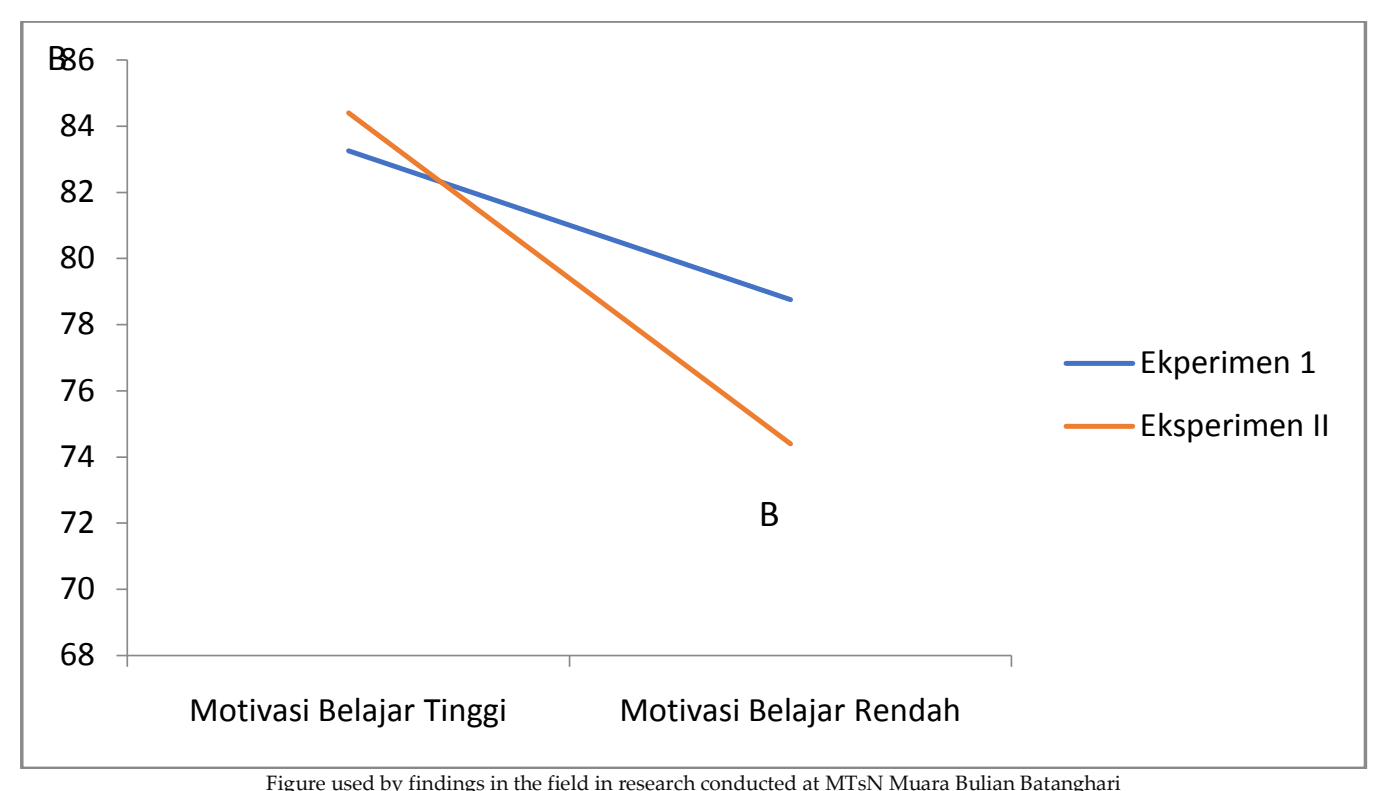

Figure \#01. <The graph of the interaction between the model and the model CIRC. GI with the motivation of learning towards intensive reading skills>

\section{Conclusion}

Based on the description, analysis, and discussion of the data of the research that has been done, then it can be summed up four things as the following. First, there is no difference between the intensive reading learning results of students taught with the learning model CIRC. with students being taught learning model with GI in grade VII MTsN Muara Bulian. The average reading skills of students who are taught in an intensive learning CIRC. was 81.00, while students taught with model GI is79.40. Second, there is no difference between the intensive reading learning outcomes of students who have a high learning motivation are taught with a model of learning that students with CIRC. have the motivation of high learning taught by model learning GI. The average reading skills of students ' learning motivation high intensive taught by learning model CIRC. was 83.25 , while higher learning motivation of students taught with model GI was 84.40 . Third, there was no difference between the intensive reading learning outcomes students with low learning motivation are taught with a model of learning that students with CIRC. have the motivation of learning low taught learning model with GI. The average reading skills of students ' learning motivation low intensive taught by learning model is whereas 78.75 CIRC. motivational belajarrendah students taught with model GI is 74.40. Fourth, there is the influence of the interaction between the learning model with learning motivation towards learning outcomes of intensive reading in grade VII MTsN Muara Bulian.

Based on the results and a summary of these suggestions indicated on the parties is as follows. First, for the school in order to improve the management of education in school can be done by providing sarana-prasarana learned that it takes for the development potential of the students and the smooth process of teaching and learning, such as provide new books as a source of new reading skills to support students in reading. Second, the language and literature teachers to Indonesia MTsN Muara Bulian. in order to motivate and provide learning models berfariasi and interesting to avoid boredom and kenejuhan students in learning. Third, students of Class VII MTsN Muara Bulian so that it can be practiced in earnest in learning, so that later the skilled in speaking not only skilled in read but also skilled against four aspects of language other that is, listening, speaking, and writing. 
Because reading is essentially a most important thing, because by reading will open and provide a breadth and their knowledge.

Note: this article was written based on the results of research for the writing of the thesis the author with the supervisor I Prof. Dr. Ermanto, M. Hum and Supervisor II Dr. Abdurahman, M. Pd.

\section{References}

Abdurahman and Ellya Ratna. (2003). Evaluation of learning the language and literature of Indonesia. Textbook. The Field: State University Of Padang.

Arikunto, Suharsimi. (2006). the procedure of research. Jakarta: Cipta Rineka.

Depertemen National Education. (2006). Guide the development of the syllabus Subjects Indonesian Language middle school. Jakarta: Directorate General management of primary and secondary education.

Dimyati and Mudjiono. Innovation Learning in class. Jakarta: Aksara Earth.

Esther Tovli. (2014). "The Joy of Reading"-An Intervention Program to Increase Reading Motivation for Pupils with Learning Disabilities. Journal of Education and Trainin. Journal. Vol. 2, no. 4; October 2014 ISSN 2324-805X E-ISSN 2324-8068 Published by Redfame Publishing URL: http://jets.redfame.com_.

James 1. Collins (2016). Bringing Together Reading and Writing: An Experimental Study of Writing Intensive Reading Comprehension in Low Performing Urban Elementary Schools. Journal. Literacy. ISSN 61577.

Istarani. (2012). the innovative Learning Model 58. Terrain: Media Persada.

Riduwan and Sunato. (2012). Introduction to Statistics: for educational research, social, communications, economics, and business. Bandung: Alfabeta.

Saddhono, Kundharu and St. y. Slamet. (2012). Designing a Model of learning: innovative, progressive, and contextual. Jakarta: Prenadamedai Group.

Slavin, R.E. (2010). Cooperatif Learning, theory, research and practice (English translation: Yusron Nurulita). Bandung: Nusa Media.

Sugiyono. (2012). a quantitative approach to Educational Research Methods, qualitative, and $R \& d$. Bandung: Alfabeta.

UNO, Hamza b. (2011). The Model of learning: creating teaching and learning in creative and effective. Jakarta: Aksara Earth.

Trianto , Ibn Badr al-Tabany. (2014). Designing a Model of learning: innovative, progressive, and contextual. Jakarta: Prenadamedai Group.

Wena, Made. (2009). Contemporary Innovative Learning Strategies: A Conceptual Overview Operasioanal. Jakarta: Aksara Earth. 